\title{
Sosialisasi dan Bakti Sosial Covid-19 di Kelurahan Sepinggan Raya Balikpapan Maslina $^{1^{*}}$; Isradi Zainal' ${ }^{2}$; Andi Surayya Mappangile ${ }^{3}$ \\ ${ }^{1}$ Universitas Balikpapan \\ I*maslina@uniba-bpn.ac.id
}

\begin{abstract}
Abstrak
Kegiatan sosialisasi dan bakti sosial Covidl-9 merupakan kegiatan pengabdian kepada masyarakat dalam upaya membantu masyarakat untuk pemenuhan kebutuhan hidup dan menyelesaikan permasalahan yang dialami masyarakat khuhsusnya dalam menangani penularan Covid-19.. Kegiatan dilaksanakan melalui program Sosialisasi dan Bakti sosial Covid-19 yang merupakan aktivitas berbasis pengabdian masyarakat untuk meningkatkan pengetahuan masyarakat tentang Upaya memutus mata rantai penularan Covid-19 dilaksanakan di RT. 2,3 dan 4 di Kelurahan Sepinggan Raya, Kecamatan Balikpapan Selatan Kota Balikpapan dengan metode pengabdian berupa kegiatan penyuluhan, demonstrasi, pembagian masker dan sembako serta penyemprotan Disenfektan dilingkungan perumahan. Hasil menunjukkan adanya respon positif pemerintah serta partisipasi aktif masyarakat yang tinggi
\end{abstract}

Kata Kunci: pengabdian masyarakat, covid19, partisipasi masyrakat

\section{Abstract}

Covid19 socialization and social service activities are community service activities in an effort to help people fulfill their life needs and solve the community problems by especially in dealing with COVID19 transmission. Activities are carried out through the Covid19 socialization and social service program which is a community service-based activity to increase public knowledge concerning efforts to break the chain of Covid19 transmission carried out in RT. 2,3 and 4 of Sepinggan Raya District, Balikpapan City with service methods in the form of counseling activities, demonstrations, distribution of masks and basic necessities and spraying Disenfektan in residential areas. The results showed a positive response from the government and active participation of community.

Keywords: community services, covid19, participation of community

\section{Pendahuluan}

Organisasi kesehatan dunia ( WHO) melalui Direktur Jenderal Adhanom Ghebreyesus secara resmi mengumumkan Virus Corona ( COVID-19) sebagai Pandemi pada tanggal 11 maret 2020. Pandemic Terjadi jika suatu penyakit menular tersebar dengan mudah dari manusia ke manusia di berbagai tempat diseluruh dunia. Hingga saat ini jumlah kasus COVID 19 diluar China telah meningkat 13 kali lipat dalam 2 pekan dan ini menimbulkan kecemasan bahwa bila tidak dilakukan antisipasi akan menimbulkan masalah yang lebih besar dan mempengaruhi segala sendi kehidupan. Pemerintah Indonesia telah menetapkan kejadian ini melalui keputusan presiden (Keppres) no. 11 tahun 2020 tentang penetapan Kedaruratan Kesehatan masyarakat Corona Virus Disease 2019 sebagai jenis penyakit yang menimbulkan kedaruratan kesehatan masyarakat, Pemerintah menetapkan bhawa wajib dilakukan upaya penanggulangan sesuai dengan ketentuan peraturan perundang undangan. Dengan diberlakukannya status KLB pemerintah telah menerapkan berbagai protokol seperti meliburkan sekolah, meliburkan berbagai kantor, menghimbau Volume 2, Nomor 2, 2020

ISSN 2657-1439 (Print), ISSN 2684-7043 (Online) bekerja, belajar dan beribadah dari rumah, menghimbau untuk menghindari kegiatan yang melibatkan banyak orang. Untuk mendukung upaya pemerintah ini maka masyarakat ikut bertanggung jawab agar selalu proaktif untuk disiplin dalam memproteksi diri sesuai himbauan pemerintah untuk menerapkan disiplin dalam melaksnakan protokol pencegahan penularan COVID-19.

Corona Virus19 adalah virus yang memiliki banyak jenis. Namanya biasanya dibedakan berdasarkan tingkat keparahan penyakit yang disebabkan dan seberapa jauh penyebarannya. Sejauh ini ada enam jenis virus corona yang diketahui menginfeksi manusia. Empat di antaranya adalah:229E,NL63,0C43,HKU1. Virus corona merupakan zoonosis, sehingga terdapat kemungkinkan virus berasal dari hewan dan ditularkan ke manusia. Belum diketahui dengan pasti proses penularan virus corona 19 dari hewan ke manusia, tetapi data filogenetik memungkinkan COVID-19 juga merupakan zoonosis. Perkembangan data selanjutnya menunjukkan penularan antar manusia (human to human), yaitu diprediksi melalui droplet ( cairan 
mulut) dan kontak dengan virus yang dikeluarkan dalam droplet.

Gejala bisa muncul 2-14 hari setelah terpapar virus. Gejala klinis bervariasi tergantung derajat penyakit tetapi gejala yang utama adalah demam, batuk, mialgia, sesak, sakit kepala, diare, mual dan nyeri abdomen. Gejala yang paling sering ditemui hingga saat ini adalah demam (98\%), batuk dan mialgia. sakit tenggorokan, kehilangan rasa atau bau baru.Masa inkubasi: 1-14 hari Cara penularan: Penularan dari manusia ke manusia melalui tetesan pernapasan, upaya pencegahan: Pencegahan utama adalah membatasi mobilisasi orang yang berisiko hingga masa inkubasi. Pencegahan lain adalah meningkatkan daya tahan tubuh melalui asupan makanan sehat, sering mencuci tangan dengan sabun dan air mengalir, menggunakan masker bila berada di daerah berisiko atau padat, menjaga kebukgaran tubh dengan rajin melakukan olah raga, istirahat yang cukup serta makan makanan yang bergizi sehat seimbang sertadimasak hingga matang dan bila sakit segera berobat ke RS rujukan untuk dievaluasi. Sampai saat ini belum ditemukan vaksinasi untuk pencegahan primer. Pencegahan sekunder adalah segera menghentikan proses pertumbuhan virus, sehingga pasien tidak lagi menjadi sumber infeksi. Upaya pencegahan yang penting termasuk berhenti merokok untuk mencegah kelainan parenkim paru. Upaya Pencegahan pada petugas kesehatan juga harus dilakukan dengan cara memperhatikan penempatan pasien di ruang rawat atau ruang intensif isolasi. Pengendalian infeksi di tempat layanan kesehatan pasien terduga di ruang instalasi gawat darurat (IGD) isolasi serta mengatur alur pasien masuk dan keluar. Pencegahan terhadap petugas kesehatan dimulai dari pintu pertama pasien termasuk triase. Pada pasien yang mungkin mengalami infeksi COVID-19 petugas kesehatan perlu menggunakan APD standar untuk penyakit menular. Kewaspadaan standar dilakukan rutin, menggunakan APD termasuk masker untuk tenaga medis (N95), Kacamata (proteksi) mata, sarung tangan dan Hasmat (baju panjang)

Untuk ikut berpartisipasi dalam upaya memutus mata rantai penularan Covid19 dengan meningkatkan pengetahuan masyarakat akan Covid19, dan upaya mengantisipasi dampak dari penularan Covid19 yang tidak hanya mempengaruhi dari sisi kesehatan namun berdampak ke hidupan sosial lainnya khususnya bidang ekonomi yang mempengaruhi pengahsilan dan pendapatan masyarakat akibat adanya pembatasan social, maka kami akan melakukan pengabdian kepada masyarakat Kelurahan Sepinggan Raya Balikpapan sebagai salah satu kelurahan yang berada di RT 2,3, 4 dan 35 Kecamatan Balikpapan Selatan Kota Balikpapan yang beralamat di Jl. Marsma R.Iswahyudi Balikpapan. Yang dilaksanakan pada tanggal 11 April 2020. Berupa program kegiatan mengedukasi Volume 2, Nomor 2, 2020

ISSN 2657-1439 (Print), ISSN 2684-7043 (Online) masyarakat dengan memberikan penyuluhan tentang protokol memutus mata rantai penularan Covid19, perilaku hidup bersih sehat, cara mencuci tangan, memakai masker, penyemprotan disenfektan dan pembagian sembako sehingga menambah pengetahuan mereka dengan harapan mereka dapat menerapkan perilaku sehat dalam kehidupan sehari-hari sebagai upaya dalam menanggulangi penularan virus Covid19.

\section{Bahan dan Metode}

Beberapa tahap yang dilakukan pada kegiatan pengabdian kepada masyarakat yang dilaksanakan di Kelurahan Sepinggan Raya Balikpapan meliputi:

2.1 Tahap persiapan:

1. Survey Lapangan: meninjau lokasi yang akan diberikan sosialisasi tentang budaya hidup sehat dan cara pencegahan covid-19 dan kegiatan bakti sosial berupa penyerahan seperangkat alat cuci tangan; masker dan sembako, dan kegiatan bakti social berupa Penyemprotan di daerah yang terdampak covid-19.

2. Pemantapan, penentuan lokasi dan sasaran

3. Persiapan perlengkapan dan peralatan berupa: materi sosialisasi, bahan-bahan kebersihan, sembako, dan alat penyemprotan beserta Alat Pelindung Diri.

2.2 Tahap Pelaksanaan

1. Metode ceramah.

Metode ceramah ini dipilih untuk memberikan penjelasan tentang budaya hidup sehat.

2. Metode tanya jawab

Metode Tanya jawab ini sangat penting dilakukan agar peserta dapat memahami dengan benar langkah-langkah yang harus dilakukan dalam mencegah dan menangani covid-19 ini.

3. Metode simulasi

Metode simulasi ini sangat penting diberikan kepada peserta untuk mempraktekan apa yang telah disampaikan oleh pemateri

4. Metode bakti sosial

Melakukan kegiatan bakti sosial pemberian langsung berupa:

a) bahan pencegahan covid-19 berupa masker, sabun cuci tangan, dan hand sanitizer.

b) bahan sembako untuk menangani sementara konsumsi sehari-hari bagi masyarakat yang terkena dampak covid19.

c) Penyemprotan disenfektan pada rumahrumah dan tempat-tempat dilingkungan RT 2, 3 dan 4 di kelurahan sepinggan raya Balikpapan.

d) Pemasangan penempelan stiker-stiker dan poster tentang pencegahan covid-19 di 
tempat-tempat yang strategis di lingkungan RT di kelurahan sepinggan raya Balikpapan.

\section{Hasil dan Pembahasan}

Kegiatan Sosialisasi dan bakti sosial yang dilakukan pada Kelurahan Sepinggan Raya Balikpapan ini pada saat pandemi covid-19 ini masih berlangsung dan merupakan daerah zona merah, sehingga dalam pelaksanaannya selalu melaksanakan protokol kesehatan. Adapun hasil dari kegiatan ini adalah sebagai berikut:

1) Sosialisasi.

Sosialisasi dilaksanakan di halaman rumah warga di RT Kelurahan Sepinggan Raya Balikpapan, karena kondisi pada saat pandemic covid-19 ini maka warga yang menghadiri juga dibatasi terdiri dari beberapa perwakilan warga pengurus posyandu dan beberapa warga yang terdampak covid19 serta Ketua RT 5 dan 6 setempat dan Lurah Sepinggan raya. Gambar 1 memperlihatkan situasi pada saat sosialisasi berlangsung.

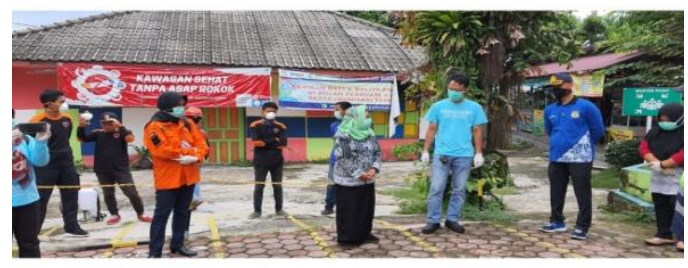

Gambar 1. Sosialisasi pengarahan budaya hidup sehat dan bersih

Materi yang diberikan pada sosialisasi tentang budaya hidup sehat dan bersih adalah:

a) Perbanyak asupan makanan bergizi.

Dengan menerapkan pola makan sehat dan penuh nutrisi. Salah satu makanan yang baik untuk daya tahan tubuh adalah makanan kaya akan vitamin $\mathrm{C}$ dan vitamin B kompleks.

b) Cukupi kebutuhan air putih.

Untuk membantu tubuh agar tidak cepat dehidrasi dan dapat meningkatkan kesehatan tubuh setidaknya minum 8 gelas sehari.

c) Olahraga Rutin.

Membiasakan olahraga sebelum melakukan aktivitas harian.

d) Istirahat cukup.

Tidur dapat membantu memaksimalkan metabolism dan menjaga daya tahan tubuh. Tidur minimal 7-8 jam setiap harinya.

e) Konsumsi multivitamin.

Membantu tubuh dalam memenuhi kebutuhan vitamin harian dengan mengkonsumsi multivitamin secara rutin, yang mengandung vitamin $\mathrm{C}$ untuk bantu meningkatkan system imunitas dan menjaga daya tahan tubuh.

f) Menggunakan masker ketika pergi keluar rumah.

Masker dapat mencegah penyebaran virus dengan melindungi bagian wajah dari droplets seseorang yang mengandung Covid-19.

g) Menerapkan physical distancing.

Dengan memastikan jaga jarak dan tidak melakukan kontak terlalu dekat dengan orang lain. Menghindari kerumunan ditempat ramai.

h) Mencuci tangan secara rutin.

Selalu cuci tangan dengan sabun dan air, terutama setelah menyentuh benda yang ada di ruang publik, dengan durasi 20 30 detik. Jika tidak ada wastafel atau toilet, gunakan hand sanitizer untuk membersihkan tangan. 6 (enam) langkah cuci tangan yang benar:

1. Telapak tangan

Cara cuci tangan yang pertama adalah dengan menggosok kedua telapak tangan. Telapak tangan adalah bagian tubuh pertama yang bertemu dengan benda lain.

2. Telapak dan punggung tangan.

Langkah kedua adalah dengan menggosok telapak tangan kiri ke punggung tangan kanan. Hal yang sama berlaku sebaliknya.

3. Kaitkan jari.

Langkah Setelah mencuci telapak dan punggung tangan, bersihkan sela-sela jari, kaitkan jemari dan gosok telapak tangan sampai bersih.

4. Punggung jari.

Langkah selanjutnya membersihkan punggung jari. Gosok punggung jari dengan arah memutar di atas telapak tangan.

5. Jempol

Karena jaraknya yang agak berjauhan dengan jari lain, maka jempol dibersihkan secara terpisah dengan cara menggenggam jempol kanan dengan tangan kiri, kemudian gosok dengan arah memutar, hal sama juga berlaku dengan jempol kiri.

6. Kuku

Kuku menjadi tempat bersarangnya kuman. Membersihkanya dengan cara kuncupkan jemari, kemudian gosok di telapak tangan. Lebih efektif bila 
kuku tidak panjang atau sering dipotong.

Setelah mencuci tangan dengan sabun, bilas menggunakan air bersih yang mengalir dan keringkan tangan.

i) Membersihkan permukaan benda dengan disinfektan.

Membersihkan barang atau benda yang sering disentuh dengan disenfektan secara rutin seperti gagang pintu, pegangan pada tangga, stop kontak, kantong belanjaan yang sering digunakan dan lain-lain.

2) Simulasi yang dilakukan ditunjukan pada gambar 2 berikut ini.

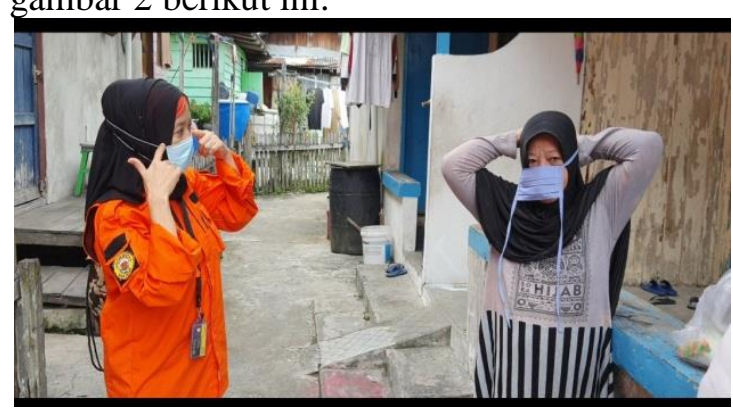

Gambar 2. Memberi contoh Cara pemakaian masker yang benar ke warga RT 3 kelurahan sepinggan raya Balikpapan

3) Bakti Sosial

Melakukan kegiatan bakti sosial pemberian langsung berupa:

a) bahan pencegahan covid-19 berupa masker, sabun cuci tangan, dan hand sanitizer. Gambar 3 dan Gambar 4 menunjukkan kegiatan pemberian

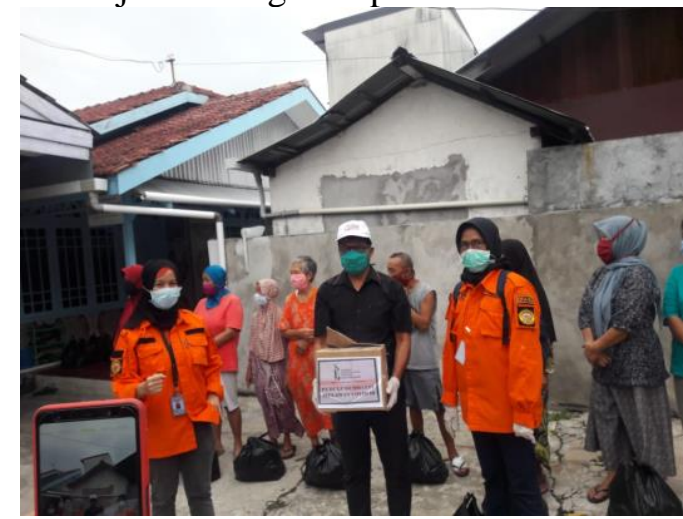

Gambar 3. Pemberian sabun cuci tangan dan hand sanitizer ke warga RT 4 kelurahan sepinggan raya Balipapan

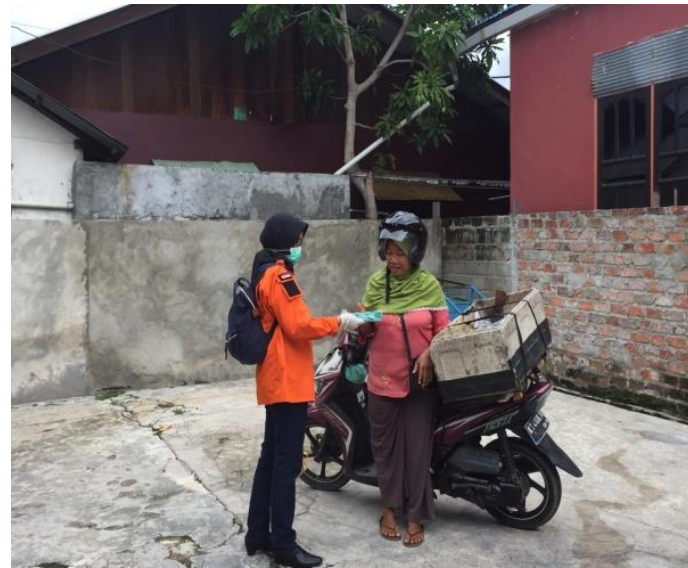

Gambar 4. Penyerahan Masker ke warga (tukang sayur keliling) di kelurahan Sepinggan Raya Balikpapan

b) Pemberian bahan sembako untuk menangani sementara konsumsi seharihari bagi masyarakat yang terkena dampak covid-19. Gambar 5 menunjukkan kegiatan penyerahan sembako.

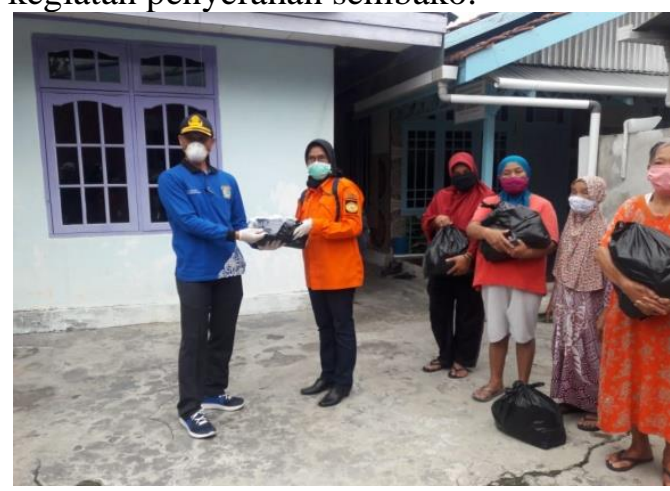

Gambar 5. Penyerahan sembako ke warga RT 35 Kelurahan Sepinggan Raya Balikpapan

c) Penyemprotan disenfektan pada rumahrumah dan tempat-tempat dilingkungan RT 2, 3 dan 4 di kelurahan sepinggan raya Balikpapan. Gambar 6 dan 7 memperlihatkan kegiatan penyemprotan.

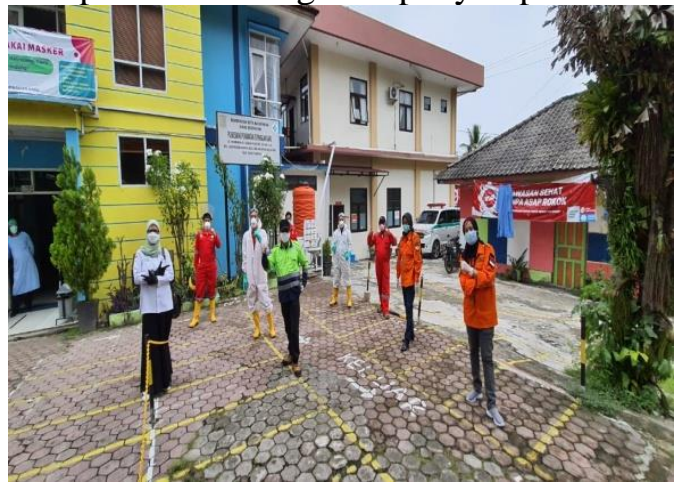

Gambar 6. Tim sosialisasi dan pelaksana penyemprotan disenfektan di kelurahan sepinggan raya Balikpapan 


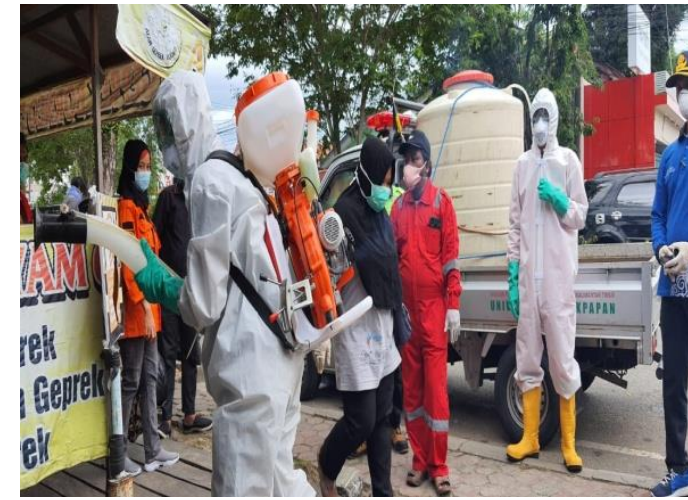

Gambar 7. Penyemprotan yang dilakukan oleh mahasiswa di rumah-rumah warga di RT di lingkungan kelurahan sepinggan raya Balikpapan

d) Pemasangan penempelan stiker-stiker dan poster tentang pencegahan covid-19 di tempat-tempat yang strategis di lingkungan RT di kelurahan sepinggan raya Balikpapan.

\section{Kesimpulan dan Saran}

Kesimpulan Kegiatan sosialiasasi dan bakti sosial Covid19 telah dilaksanakan sesuai dengan rencana berkat kerjasama dan dukungan dari berbagai pihak, Pihak kecamatan dan kelurahan, puskesmas dan masyarakat umum. Kegiatan pengabdian masyarakat ini dalam bentuk penyuluhan tentang Upaya memutus mata rantai penularan Covid19 yang dirangkaikan dengan pembagian masker, pembagian sabun cuci tangan dan penyemprotan disinfektan, memberikan pemahaman serta observasi , dimana membantu para masyarakat umum menambah wawasan mereka tentang kesehatan diri yang diharapkan akan membentuk perilaku positif dan menjadikan sebagai suatu perilaku sehat yang bisa menjadi role model bagi keluarga dan masyarakat.

Pemerintah kelurahan dan masyarakat kelurahan Sepinggan sangat antusias menyambut dengan baik kegiatan ini, masyarakat sangat senang apalagi dengan pemberian masker gratis, sembako serta penyemprotan disenfektan.

\section{Ucapan Terima Kasih}

Kami sebagai penyelenggara kegiatan pengabdian kepada masyarakat mengucapkan banyak terima kasih kepada semua pihak yang telah berpartisipasi dalam membantu kelancaran kegaitan ini, pihak Kelurahan Sepinggan beserta staf, Ketua RT yang mendampingi selama kegiatan berlangsung, sumbangan masker dan sembako dari pihak donator. Harapannya kegiatan ini memberikan manfaat bagi masyarakat dan memberi kontribusi nyata dalam upaya memutus mata rantai penularan Virus Corona19.

\section{Daftar Rujukan}

Djalante R, Lassa J, Setiamarga D, Sudjatma A, Indrawan M. (2020). Review and analysis of current responses to COVID-19 in Indonesia: Period of January to March 2020 .

Cucinotta, D., \& Vanelli M. (2020). WHO declares COVID-19 a pandemic. Acta biomedica Atenei Parm

Keputusan presiden (Keppres) no. 11 tahun 2020 tentang penetapan Kedaruratan Kesehatan masyarakat Corona Virus Disease 2019.

Handayani, D., Hadi, D. R., Isbaniah, F., Burhan, E., \& Agustin H. (2019). Corona Virus Disease. Jurnal Respirologi Indonesia, 40(2), 119-129.

Ha BTT, Quang LN, Mirzoev T, Tai NT, Thai PQ, Dinh PC. (2020). Combating the COVID-19 epidemic: Experiences from Vietnam. Int J Environ Res Public Health, 17(9).

Saputra, M., Arsyi, M., Nurhanifah, N., Octavia, S. N., \& Pratomo H. (2020). Evaluasi Pedoman Penanganan Cepat Medis dan Kesehatan Masyarakat tentang Coronavirus Disease (COVID-19) di Indonesia. J Ilm Ilmu Keperawatan Indones 10(02), 8-17.

Hernández-Padilla JM, Granero-Molina J, RuizFernández MD, Dobarrio-Sanz I, LópezRodríguez MM, Fernández-Medina IM, et al. (2020). Design and psychometric analysis of the COVID-19 prevention, recognition and home-management selfefficacy scale. Int $\mathbf{J}$ Environ Res Public Health, 17(13), 1-14.

Notoatmodjo S. (2010). Promosi Kesehatan Masyarakat Teori dan Aplikasi. Jakarta.

Kemenkes RI (2020). Pedoman Pencegahan dan Pengendalian Coronavirus Disease (COVID-19). 2020.

Wawan \& Dewi A. Pengetahuan, Sikap dan Perilaku Manusia. Yogyakarta. 